\title{
The health of Saudi youths: current challenges and future opportunities
}

\author{
Maziar Moradi-Lakeh ${ }^{1}$, Charbel El Bcheraoui ${ }^{1}$, Marwa Tuffaha'', Farah Daoud ${ }^{1}$, Mohammad Al Saeedi², \\ Mohammed Basulaiman², Ziad A. Memish², Mohammad A. Al Mazroa², Abdullah A. Al Rabeeah² \\ and Ali H. Mokdad ${ }^{1 *}$
}

\begin{abstract}
Background: The health status of the young people is an important indicator for future health and health care needs of the next generation. In order to understand the health risk factors of Saudi youth, we analyzed data from a large national survey in the Kingdom of Saudi Arabia.

Methods: The Saudi Health Information Survey sample included 2382 youths aged 15 to 24 years old. The questionnaire included information on socio-demographic characteristics, risk factors, risky behaviors, chronic conditions, functional status, health care utilization, and anthropometric and blood pressure measurements.

Results: Only $45.9 \%$ of men and $48.4 \%$ of women had normal body mass index (BMI). Men were more likely than women to smoke cigarettes or shisha. The prevalence of daily consumption of at least five servings of fruits and vegetables was $6.6 \%$. The prevalence of no or insufficient physical activity was $41.8 \%$ in men and $75.6 \%$ in women $(P<0.001)$. Around $40 \%$ of men and $25 \%$ of women had abnormal blood pressure. Mean BMI and prevalence of insufficient physical activity, current smoking, and hypertension was higher in 20-to 24-year-olds than younger ages. Women were more likely to report that they never use seatbelts ( $82.2 \%$ vs. $65.4 \%$ ).

Conclusions: The prevalence of modifiable risk factors and risky driving behaviors is very high among Saudi youth. If these current behaviors are not reversed during this crucial age period, the burden of disease and injuries will rise in the future. Our findings call for developing health prevention programs for youths in Saudi Arabia.
\end{abstract}

Keywords: Adolescent, Youth, Health status, Risk factors, Saudi Arabia

\section{Background}

The United Nations Secretariat defines youths as those aged 15 to 24 years old. The youth period is a time of transition from the dependence of childhood to the independence of adulthood [1]. The health status of the young people in a population is an important indicator for future health and health care needs of the next generation. Patton et al. argued that there are good opportunities for health gains both through prevention and early clinical intervention in this period of life. They recommended a list of indicators for monitoring health status of youth and adolescence [2]. Many of the preventable risky behaviors, such as misuse of alcohol, tobacco, drugs, unsafe sex,

\footnotetext{
* Correspondence: mokdaa@uw.edu

${ }^{1}$ Institute for Health Metrics and Evaluation, University of Washington, 2301

Fifth Ave, Suite 600, Seattle, WA 98121, USA

Full list of author information is available at the end of the article
}

unsafe driving, and violence, are usually established during the youth period [3]. Indeed, youth is an important formative period for patterns of behavior that endure into adulthood [4].

The Kingdom of Saudi Arabia (KSA) has a young population; more than half of the population is younger than 25 years, and approximately $14 \%$ of Saudis are aged 15 to 24 years old [5]. The KSA burden of disease, injuries, and risk factors study showed that mental and behavioral disorders, injuries, and other non-communicable diseases are the leading causes of disease burden in Saudi youths [6]. Few other studies have reported specific aspects of the health of young people in KSA, such as overweight and obesity [7-9], nutritional status [10-13], or specific diseases. Moreover, most of the previous studies are not generalizable to all Saudi youths due to limitations to specific geographical areas (such as a province or city) or to 
specific populations (such as students). In order to describe the current status of diseases, health risk factors, and healthcare utilization among Saudi youths (15-to 24-year-old individuals), we analyzed data from a large national household survey in KSA.

\section{Methods}

The Saudi Health Information Survey (SHIS) was a cross-sectional national multistage survey of individuals aged 15 years or older performed between April and June 2013. For the purpose of this survey, KSA was divided into 13 regions, and each region was divided into subregions and blocks. All regions were included, and a probability proportional to size method was used to randomly select subregions and blocks. Households were randomly selected from each block. A roster of household members was conducted, and one individual aged 15 or older was randomly selected from the household to be surveyed. If the randomly selected person was not present, surveyors made another appointment to return, up to three times, before considering the household as a nonresponse. For the current study, we selected the subsample of 15-to 24-year-old youths from the SHIS dataset. More details on the methods and other findings of this survey are available in previously published reports [14-20].

\section{Ethics, consent and permissions}

The Saudi Ministry of Health and its Institutional Review Board (IRB) approved the study protocol. The University of Washington IRB deemed the study as IRB-exempt, since the Institute for Health Metrics and Evaluation received de-identified data for this analysis. All respondents consented and agreed to participate in the study. If the respondent was between the ages of 15 and 17 years old, the parent (s) or legal guardian of that individual consented as well.

Trained local health professional staff performed the interviews with same-sex respondents.

The survey included questions on socio-demographic characteristics, a selected list of risk factors, chronic conditions, functional status, and health care use.

We measured self-rated health by asking respondents "In general, would you say your health is excellent, very good, good, fair, or poor?" with a per-question explanation about its timeframe during the past 30 days.

Individuals were classified into three groups of never smokers, former smokers, and current smokers through two questions: "Have you ever smoked any tobacco products, such as cigarettes, cigars or pipes, or shisha?" and "Do you currently smoke any tobacco products, such as cigarettes, cigars, pipes or shisha?" Interviewers also asked respondents about daily use of shisha, pipe, or flavored shisha, which was considered as daily shisha smoking.
A total of three blood measurements were taken with the participant resting and at five-minute intervals. The guidelines of the National Health and Nutrition Examination Survey (NHANES) were used for measuring blood pressure levels [21]. Individuals were classified based on measures of systolic (SBP) and diastolic blood pressure (DBP) as having: normal blood pressure (SBP $\leq 120$ and $\mathrm{DBP} \leq 80)$, pre-hypertension $(120<\mathrm{SB} P<140$ or $80<$ $\mathrm{DB} P<90)$, Stage 1 hypertension $(140 \leq \mathrm{SB} P<160$ or $90 \leq \mathrm{DB} P<100)$, and Stage 2 hypertension (SBP $\geq 160$ or $\mathrm{DBP} \geq 100$ ).

Trained interviewers measured weight and height to calculate body mass index (BMI) as $\mathrm{kg} / \mathrm{m}^{2}$. Participants were classified into four groups: underweight $(\mathrm{BMI}<18.5)$, normal weight $(18.5 \leq \mathrm{BMI}<25)$, overweight $(25 \leq \mathrm{BMI}<30)$, and obese (BMI $\geq 30$ ).

We used the short form of the International Physical Activity questionnaire to measure physical activity in occupational and recreational settings. The respondents were classified into four groups: met vigorous physical activity, met moderate physical activity, insufficient physical activity to meet vigorous or moderate levels, and no physical activity [22].

Respondents were asked, "In a typical week, how much time do you usually spend in front of the television or on the computer?" Respondents were also asked to rate their ability to perform activities. They were asked for their ability to perform vigorous activities ("Does your health now limit you in doing vigorous activities, such as running, lifting heavy objects, or participating in strenuous sports?"), mild activities ("During the past 30 days, how difficult was it to perform any of the following activities: walking a short distance, standing from a seated position, standing for a short period of time, climbing one step of stairs?"), their usual work or house activities ("During the past 30 days, how difficult was it to perform your work or house activities?"), and specific functional abilities ("Are you able to climb up five steps?"). Interviewers also asked whether or not the respondent required the use of special equipment such as a cane, a wheelchair, a special bed, or a special telephone.

We computed the servings of fruits and vegetables consumed per day from a detailed dietary questionnaire as the sum of the average daily servings. Respondents were asked, "In a typical week, how many days do you eat processed meats such as sausage, or other packaged cold cuts, lunch meats, or deli meats?" and "How many servings of processed meats do you eat on one of those days?" Similar questions were asked for "other processed foods, such as fast foods, canned foods, packaged entrees, or soup," "fast foods," and "regular soda or pop that contains sugar, sweetened iced teas, sports drinks, or fruit drinks." 
To assess diagnosed cases of asthma, diabetes mellitus (and type of diabetes), congestive heart failure, renal failure, and cancer, interviewers asked, "Has a doctor or other health professional ever told you that you had [that condition]?" Questions about talking on a mobile or using a handset or hands-free device while driving, following speed limits, and using seatbelts in different settings of driving or traveling in a car were asked in order to assess driving safety.

We used stata 13.1 for Windows (StataCorp LP, TX, USA) for survey analysis. Data were weighted to account for the probability of selection and age and sex poststratification. We used individual sampling weights to account for the probability of selecting a respondent within a household, the probability of selecting a household within a stratum, and the post-stratification differences in age-and sex-distribution between the Saudi population and the sample.

Descriptive data are reported as percent and standard error (SE) for categorical variables or mean and SE for numerical variables. We used stepwise multivariate logistic regression. We used Chi-square and pooled t tests to compare measures between subcategories of sex or between younger (15-to 19-year-old) and older (20-to 24-year-old) youths.

\section{Results}

There were 2382 individuals 15 to 24 years old in the SHIS database (response rate for SHIS: 89.4\%). Table 1 describes the socio-demographic characteristics of this sample. About $14 \%$ of female and $3 \%$ of male youths reported a history of marriage. Among youths under the age of $18,1.9 \%(n=7)$ of boys and $3.9 \%(n=20)$ of girls reported a history of marriage; these percentages were $3.2 \%$ and $13.8 \%$ among all male and female youths, respectively. College education (any education after completing high school) was higher among women than men $(P<0.001)$, however, the percentage of current (school or university) students was higher in men. The percentage of men who had a paid job was twice that of women. Approximately $27 \%$ of youth classified as "other" work status (including those who had unpaid jobs, were unemployed or unable to work, and homemakers) had college or higher education; the percentage of this other work status was 8.1 times higher for women than for men.

Self-rated health did not vary by age. About $65 \%$ of respondents reported that their health was excellent. Less than half of respondents had normal BMI $\left(18.5-24.9 \mathrm{~kg} / \mathrm{m}^{2}\right)$. Underweight, overweight, and obesity did not vary significantly by sex. Prevalence of overweight or obesity in men and women was $38.2 \%$ and $43.9 \%$, respectively. BMI increased with age from $23.5( \pm 0.2)$ in those aged 15 to 19 years to 25.1 $( \pm 0.2) \mathrm{kg} / \mathrm{m}^{2}$ in those 20 to 24 years old $(P<0.001)$. Men were more likely than women to smoke cigarettes $(16.1 \%$ current smoking in men versus $0.8 \%$ in women) or shisha (5.0 \% daily shisha smoking in men versus $1.0 \%$ in women). The average pack years of smoking for current smokers was $3.43(\mathrm{SE}=0.42)$ for men and $0.12(\mathrm{SE}=0.08)$ for women. Smoking was much higher in the older age group (Table 3).

The prevalence of daily consumption of at least five servings of fruits and vegetables was low in both sexes $(6.6 \%)$ and did not vary by age (Table 2$)$. Men reported higher levels of physical activity than women (Table 2); $19.7 \%$ of men and $42.8 \%$ of women were classified as inactive based on their reported levels of physical activity. Overall, physical activity was very low and even lower among older youth (Table 3). Men were more

Table 1 Socio-demographic characteristics of Saudi youths by sex, 2013

\begin{tabular}{|c|c|c|c|c|c|c|c|c|c|c|}
\hline \multirow[t]{2}{*}{ Factor } & \multirow[t]{2}{*}{ Categories } & \multicolumn{3}{|l|}{ Male } & \multicolumn{3}{|c|}{ Female } & \multicolumn{3}{|c|}{ Both sexes } \\
\hline & & N & Weighted \% & SE & $\mathrm{N}$ & Weighted \% & SE & N & Weighted \% & SE \\
\hline \multirow[t]{2}{*}{ Age } & $15-19$ years & 677 & 58.6 & 1.8 & 547 & 48.5 & 1.9 & 1224 & 53.7 & 1.3 \\
\hline & $20-24$ years & 512 & 41.4 & 1.8 & 646 & 51.5 & 1.9 & 1158 & 46.3 & 1.3 \\
\hline \multirow[t]{3}{*}{ Education } & Primary school or less & 153 & 14.5 & 1.3 & 175 & 14.9 & 1.4 & 328 & 14.7 & 0.9 \\
\hline & Elementary/high school & 941 & 76.5 & 1.6 & 824 & 68.4 & 1.8 & 1765 & 72.6 & 1.2 \\
\hline & College or higher education & 94 & 9.0 & 1.1 & 192 & 16.7 & 1.4 & 286 & 12.8 & 0.9 \\
\hline \multirow[t]{3}{*}{ Marital status } & Never married & 1135 & 96.8 & 0.6 & 925 & 86.2 & 1.1 & 2060 & 91.6 & 0.6 \\
\hline & Currently married & 53 & 2.9 & 0.5 & 252 & 12.3 & 1.0 & 305 & 7.5 & 0.6 \\
\hline & Separated, divorced, widowed & 1 & 0.3 & 0.3 & 16 & 1.6 & 0.5 & 17 & 0.9 & 0.3 \\
\hline \multirow[t]{4}{*}{ Work status } & Employed & 145 & 10.9 & 1.1 & 65 & 5.5 & 0.9 & 210 & 8.2 & 0.7 \\
\hline & Student & 933 & 80.6 & 1.4 & 795 & 70.7 & 1.7 & 1728 & 75.8 & 1.1 \\
\hline & Unemployed & 96 & 6.7 & 0.9 & 112 & 9.0 & 1.1 & 208 & 7.8 & 0.7 \\
\hline & Other & 15 & 1.8 & 0.6 & 221 & 14.9 & 1.3 & 236 & 8.2 & 0.7 \\
\hline
\end{tabular}


Table 2 Risk factors of health among Saudi youths by sex, 2013

\begin{tabular}{|c|c|c|c|c|c|c|c|c|}
\hline \multirow[t]{2}{*}{ Factor } & \multirow[t]{2}{*}{ Categories } & \multicolumn{3}{|l|}{ Male } & \multicolumn{3}{|c|}{ Female } & \multirow[t]{2}{*}{$P$ value } \\
\hline & & $\mathrm{N}$ & Percent/Mean & SE & $\mathrm{N}$ & Percent/Mean & SE & \\
\hline \multirow[t]{4}{*}{ BMI (\%) } & $<18.5 \mathrm{Kg} / \mathrm{m}^{2}$ & 164 & 14.4 & 1.3 & 131 & 12.3 & 1.3 & 0.564 \\
\hline & $18.5-24.9 \mathrm{Kg} / \mathrm{m}^{2}$ & 544 & 47.5 & 1.9 & 568 & 50.5 & 1.9 & \\
\hline & $25-29.9 \mathrm{Kg} / \mathrm{m}^{2}$ & 284 & 24.9 & 1.6 & 272 & 23.4 & 1.6 & \\
\hline & $30+\mathrm{Kg} / \mathrm{m}^{2}$ & 157 & 13.3 & 1.3 & 170 & 13.9 & 1.3 & \\
\hline \multirow[t]{3}{*}{ Smoking (\%) } & Never smoked & 943 & 81.2 & 1.5 & 1169 & 98.5 & 0.5 & $<0.001$ \\
\hline & Former smoker & 42 & 2.7 & 0.6 & 8 & 0.8 & 0.4 & \\
\hline & Current smoker & 202 & 16.1 & 1.4 & 11 & 0.8 & 0.3 & \\
\hline \multirow[t]{2}{*}{ Shisha (\%) } & Daily users & 60 & 5.0 & 0.8 & 15 & 1.0 & 0.4 & $<0.001$ \\
\hline & Others & 1113 & 95.0 & 0.8 & 1178 & 99.0 & 0.4 & \\
\hline \multirow[t]{3}{*}{ Fruit and vegetables (\%) } & No servings & 407 & 37.5 & 1.8 & 442 & 39.0 & 1.8 & 0.073 \\
\hline & 1 to 4 servings & 718 & 57.2 & 1.8 & 683 & 53.0 & 1.9 & \\
\hline & 5 or more servings & 64 & 5.3 & 0.8 & 68 & 8.0 & 1.1 & \\
\hline \multirow[t]{4}{*}{ Activity (\%) } & No physical activity & 255 & 19.7 & 1.4 & 532 & 42.8 & 1.9 & $<0.001$ \\
\hline & Insufficient & 245 & 22.1 & 1.6 & 346 & 32.8 & 1.8 & \\
\hline & Moderate & 177 & 16.1 & 1.4 & 113 & 9.0 & 1.0 & \\
\hline & Vigorous & 479 & 42.1 & 1.9 & 174 & 15.4 & 1.4 & \\
\hline \multirow[t]{4}{*}{ Blood pressure (\%) } & Normal blood pressure & 741 & 64.38 & 1.81 & 908 & 79.54 & 1.54 & $<0.001$ \\
\hline & Prehypertension & 362 & 31.26 & 1.76 & 218 & 18.00 & 1.45 & \\
\hline & Stage 1 hypertension & 44 & 3.93 & 0.74 & 18 & 2.00 & 0.60 & \\
\hline & Stage 2 hypertension & 5 & 0.43 & 0.24 & 5 & 0.46 & 0.24 & \\
\hline \multicolumn{2}{|l|}{ Daily sitting time (hr) } & 1129 & 4.4 & 0.1 & 1113 & 4.7 & 0.1 & 0.022 \\
\hline \multicolumn{2}{|l|}{ Weekly TV and computer time (hr) } & 1137 & 7.8 & 0.4 & 117 & 7.9 & 0.4 & 0.874 \\
\hline \multicolumn{2}{|l|}{ Days eating fast food (per week) } & 1080 & 2.6 & 0.1 & 1057 & 1.9 & 0.1 & $<0.001$ \\
\hline \multicolumn{2}{|l|}{ Soda or pop ${ }^{a}$ (numbers per week) } & 1064 & 2.2 & 0.1 & 968 & 2.5 & 0.2 & 0.180 \\
\hline \multicolumn{2}{|l|}{ Days eating processed meat (per week) } & 1120 & 0.7 & 0.1 & 1098 & 0.6 & 0.0 & 0.176 \\
\hline \multicolumn{2}{|l|}{ Processed meat (servings per day) } & 310 & 1.6 & 0.1 & 296 & 1.5 & 0.1 & 0.243 \\
\hline \multicolumn{2}{|c|}{ Days eating other processed food (per week) } & 1125 & 1.6 & 0.1 & 1113 & 1.4 & 0.1 & 0.030 \\
\hline \multicolumn{2}{|l|}{ Other processed food (servings per day) } & 674 & 1.6 & 0.1 & 633 & 1.4 & 0.1 & 0.007 \\
\hline \multirow[t]{3}{*}{ Uses seatbelt as front passenger (\%) } & Never & 789 & 65.4 & 1.8 & 949 & 82.2 & 1.4 & $<0.001$ \\
\hline & Sometimes & 323 & 30.3 & 1.7 & 196 & 16.1 & 1.4 & \\
\hline & Always & 59 & 4.4 & 0.7 & 20 & 1.7 & 0.5 & \\
\hline \multirow[t]{3}{*}{ Uses seatbelt as back passenger (\%) } & Never & 1039 & 89.1 & 1.1 & 1079 & 91.7 & 1.1 & 0.238 \\
\hline & Sometimes & 111 & 9.9 & 1.1 & 81 & 7.6 & 1.0 & \\
\hline & Always & 23 & 1.0 & 0.2 & 9 & 0.7 & 0.3 & \\
\hline
\end{tabular}

${ }^{\mathrm{a}}$ Carbonated soft drinks

likely to consume fast food and processed food (Table 2). Around $7.0 \%(S E=0.9)$ of men and $14.9 \%(S E=1.3)$ of women reported that they never drink soda or pop in a regular week. Consumption of processed food (other than meat) was marginally higher in the older ages (Table 3). Women were more likely to report never using seatbelts as passengers than men $(82.2 \%$ vs. $65.4 \%$ ). Younger males were more likely to report using handset cellphones and less likely to use seatbelts than older males. High blood pressure and diagnosed cases of asthma were more common in male youth. Those aged 20 to 24 years were more likely to have high blood pressure (Tables 2 and 3 ).

The prevalence of diagnosed diabetes mellitus was not different by sex ( $0.8 \%$ in male and $0.9 \%$ in female). There were no significant differences in prevalence of diagnosed diabetes mellitus between those aged 15 to 19 years and those aged 20 to 24 years. 
Table 3 Comparison of risk factors of health in 15 to 19 year olds and 20 to 24 year olds in Saudi Arabia, 2013

\begin{tabular}{|c|c|c|c|c|c|c|c|c|}
\hline \multirow[t]{2}{*}{ Factor } & \multirow[t]{2}{*}{ Categories } & \multicolumn{3}{|c|}{$15-19$ years } & \multicolumn{3}{|c|}{ 20-24 years } & \multirow[t]{2}{*}{$P$ value } \\
\hline & & $\mathrm{N}$ & Percent/Mean & SE & $\mathrm{N}$ & Percent/Mean & SE & \\
\hline \multirow[t]{4}{*}{ BMI (\%) } & $<18.5 \mathrm{Kg} / \mathrm{m}^{2}$ & 196 & 17.2 & 1.4 & 99 & 8.9 & 1.1 & $<0.001$ \\
\hline & $18.5-24.9 \mathrm{Kg} / \mathrm{m}^{2}$ & 601 & 50.4 & 1.8 & 511 & 47.2 & 2.0 & \\
\hline & $25-29.9 \mathrm{Kg} / \mathrm{m}^{2}$ & 242 & 20.9 & 1.5 & 314 & 28.0 & 1.7 & \\
\hline & $30+\mathrm{Kg} / \mathrm{m}^{2}$ & 141 & 11.6 & 1.2 & 186 & 15.9 & 1.4 & \\
\hline \multirow[t]{3}{*}{ Smoking (\%) } & Never smoked & 1148 & 94.4 & 0.9 & 964 & 84.0 & 1.4 & $<0.001$ \\
\hline & Former smoker & 26 & 2.1 & 0.5 & 24 & 1.4 & 0.4 & \\
\hline & Current smoker & 49 & 3.5 & 0.7 & 164 & 14.6 & 1.4 & \\
\hline \multirow[t]{2}{*}{ Shisha (\%) } & Daily users & 19 & 1.5 & 0.4 & 56 & 4.8 & 0.9 & $<0.001$ \\
\hline & Others & 1199 & 98.5 & 0.4 & 1092 & 95.2 & 0.9 & \\
\hline \multirow[t]{3}{*}{ Fruit and vegetables (\%) } & No servings & 462 & 39.8 & 1.8 & 387 & 36.6 & 1.9 & 0.472 \\
\hline & 1 to 4 servings & 694 & 53.9 & 1.8 & 707 & 56.5 & 1.9 & \\
\hline & 5 or more servings & 68 & 6.3 & 0.9 & 64 & 6.9 & 1.1 & \\
\hline \multirow[t]{4}{*}{ Activity (\%) } & No physical activity & 325 & 25.1 & 1.6 & 462 & 37.7 & 1.9 & $<0.001$ \\
\hline & Insufficient & 321 & 29.0 & 1.7 & 270 & 25.4 & 1.7 & \\
\hline & Moderate & 155 & 12.6 & 1.2 & 135 & 12.7 & 1.3 & \\
\hline & Vigorous & 389 & 33.3 & 1.7 & 264 & 24.2 & 1.7 & \\
\hline \multirow[t]{4}{*}{ Blood pressure (\%) } & Normal blood pressure & 909 & 77.2 & 1.56 & 740 & 65.45 & 1.88 & $<0.001$ \\
\hline & Prehypertension & 251 & 20.8 & 1.51 & 329 & 29.55 & 1.80 & \\
\hline & Stage 1 hypertension & 21 & 1.68 & 0.45 & 41 & 4.53 & 0.89 & \\
\hline & Stage 2 hypertension & 6 & 0.43 & 0.21 & 4 & .46 & 0.27 & \\
\hline Daily sitting time (hr) & & 1155 & 4.5 & 0.1 & 1087 & 4.6 & 0.1 & 0.444 \\
\hline Weekly TV and computer time (hr) & & 1165 & 7.6 & 0.3 & 1089 & 8.1 & 0.4 & 0.360 \\
\hline Days eating fast food (per week) & & 1113 & 2.2 & 0.1 & 1024 & 2.3 & 0.1 & 0.459 \\
\hline Soda or pop ${ }^{a}$ (Numbers per week) & & 1074 & 2.3 & 0.1 & 958 & 2.4 & 0.2 & 0.696 \\
\hline Days eating processed meat (per week) & & 1157 & 0.6 & 0.05 & 1061 & 0.7 & 0.1 & 0.204 \\
\hline Processed meat (servings per day) & & 304 & 1.6 & 0.1 & 302 & 1.5 & 0.1 & 0.511 \\
\hline Days eating other processed food (per week) & & 1160 & 1.4 & 0.1 & 1078 & 1.6 & 0.1 & 0.049 \\
\hline Other processed food (servings per day) & & 679 & 1.5 & 0.05 & 628 & 1.6 & 0.1 & 0.073 \\
\hline \multirow[t]{3}{*}{ Uses handset cell phone while driving ${ }^{\mathrm{b}}(\%)$} & Never & 100 & 21.3 & 2.4 & 64 & 11.4 & 1.7 & 0.003 \\
\hline & Sometimes & 329 & 70.1 & 2.7 & 362 & 75.5 & 2.6 & \\
\hline & Always & 40 & 8.6 & 1.7 & 46 & 13.1 & 2.3 & \\
\hline \multirow[t]{3}{*}{ Uses hands-free cell phone while driving ${ }^{b}(\%)$} & Never & 348 & 72.7 & 2.6 & 326 & 68.4 & 2.8 & 0.439 \\
\hline & Sometimes & 109 & 23.4 & 2.5 & 127 & 28.0 & 2.7 & \\
\hline & Always & 19 & 3.9 & 1.0 & 19 & 3.6 & 1.1 & \\
\hline \multirow[t]{3}{*}{ Follows speed limits ${ }^{\mathrm{b}}(\%)$} & Never & 113 & 24.1 & 2.5 & 95 & 20.6 & 2.4 & 0.387 \\
\hline & Sometimes & 237 & 51.5 & 3.0 & 279 & 57.3 & 3.0 & \\
\hline & Always & 103 & 24.4 & 2.7 & 93 & 22.1 & 2.6 & \\
\hline \multirow[t]{3}{*}{ Uses seatbelt while driving ${ }^{b}(\%)$} & Never & 299 & 60.6 & 2.9 & 239 & 48.6 & 3.0 & 0.007 \\
\hline & Sometimes & 155 & 34.6 & 2.8 & 206 & 46.9 & 3.0 & \\
\hline & Always & 24 & 4.8 & 1.2 & 28 & 4.4 & 1.0 & \\
\hline Uses seatbelt as front passenger (\%) & Never & 917 & 75.3 & 1.6 & 821 & 71.4 & 1.8 & 0.248 \\
\hline
\end{tabular}


Table 3 Comparison of risk factors of health in 15 to 19 year olds and 20 to 24 year olds in Saudi Arabia, 2013 (Continued)

\begin{tabular}{llrrrrrrr}
\hline & Sometimes & 253 & 21.9 & 1.5 & 266 & 25.1 & 1.7 & \\
& Always & 33 & 2.8 & 0.7 & 46 & 3.5 & 0.6 & \\
& Uses seatbelt as back passenger (\%) & 1098 & 90.6 & 1.1 & 1020 & 90.2 & 1.1 & 0.800 \\
& Sometimes & 91 & 8.5 & 1.1 & 101 & 9.1 & 1.0 & 0.7 \\
& Always & 16 & 0.9 & 0.3 & 16 & 0.7 & 0.2 \\
\hline
\end{tabular}

${ }^{a}$ Carbonated soft drinks

${ }^{b}$ Only men answered this item

Women were more likely to report having limitations in performing vigorous physical activities $(24.7 \%$ versus $12.6 \%)$ and usual housework activities $(9.8 \%$ versus $5.2 \%)$ than men. Around $0.17 \%$ of respondents needed special equipment due to health problems. Deafness or trouble in hearing was reported by $3.0 \%$ of men compared to $1.5 \%$ of women. However, there were no significant difference between those aged 15 to 19 years and those aged 20 to 24 years (Table 4 ).

Use of health care services was not significantly different between men and women. A notable proportion of respondents ( $46.2 \%$ of men and $44.1 \%$ of women) had visited a hospital for medical attention in the past
12 months. Injury was the reason for visiting a hospital in $11.7 \%(n=80)$ of men compared to $2 \%(n=17)$ of women. Injury was also a more common reason for visiting a hospital for those aged 15 to 19 years than for those aged 20 to 24 years ( $8.8 \%$ versus $4.8 \%$ ). Outpatient clinic and physician office visits were less frequently reported than hospital visits (Table 5). As for hospital visits, injury was a more common reason for males than females to visit an outpatient clinic (7.6\% versus $1.7 \%$ ) or a physician office (9.4\% versus $1.9 \%$ ). Both routine medical checkups and oral examinations were more common in those aged 20 to 24 years compared to those aged 15 to 19 years (Table 5).

Table 4 Indicators of physical functioning in Saudi youths by sex, 2013

\begin{tabular}{|c|c|c|c|c|c|c|c|c|}
\hline \multirow[t]{2}{*}{ Factors } & \multirow[t]{2}{*}{ Categories } & \multicolumn{3}{|l|}{ Male } & \multicolumn{3}{|c|}{ Female } & \multirow[t]{2}{*}{$P$ value } \\
\hline & & $\mathrm{N}$ & Percent & SE & $\mathrm{N}$ & Percent & SE & \\
\hline \multirow[t]{2}{*}{ Limitation in vigorous physical activity } & No & 1032 & 87.4 & 1.2 & 871 & 75.3 & 1.7 & $<0.001$ \\
\hline & Yes & 145 & 12.6 & 1.2 & 272 & 24.7 & 1.7 & \\
\hline \multirow[t]{2}{*}{ Need for special equipment } & No & 1176 & 99.7 & 0.1 & 1183 & 99.9 & 0.0 & 0.056 \\
\hline & Yes & 7 & 0.3 & 0.1 & 2 & 0.1 & 0.0 & \\
\hline \multirow[t]{5}{*}{ Able to climb five steps? } & Without any difficulty & 1148 & 96.0 & 0.8 & 1099 & 94.7 & 0.8 & 0.164 \\
\hline & With a little difficulty & 26 & 2.3 & 0.5 & 60 & 4.1 & 0.7 & \\
\hline & With some difficulty & 11 & 1.5 & 0.6 & 10 & 1.1 & 0.4 & \\
\hline & With much difficulty & 2 & 0.1 & 0.0 & 2 & 0.1 & 0.1 & \\
\hline & Unable to do & 2 & 0.1 & 0.1 & 0 & 0.0 & - & \\
\hline \multirow{5}{*}{$\begin{array}{l}\text { Difficulty in performing } \\
\text { house/work activities? }\end{array}$} & Without any difficulty & 1100 & 94.8 & 0.9 & 1018 & 90.2 & 1.1 & 0.007 \\
\hline & With a little difficulty & 40 & 3.9 & 0.8 & 102 & 7.1 & 0.9 & \\
\hline & With some difficulty & 9 & 1.0 & 0.5 & 27 & 2.5 & 0.6 & \\
\hline & With much difficulty & 3 & 0.3 & 0.2 & 4 & 0.2 & 0.1 & \\
\hline & Unable to do & 2 & 0.1 & 0.1 & 0 & 0.0 & - & \\
\hline \multirow[t]{2}{*}{ Wears glasses or contact lens } & No & 1050 & 89.4 & 1.1 & 1027 & 85.1 & 1.3 & 0.016 \\
\hline & Yes & 133 & 10.6 & 1.1 & 162 & 14.9 & 1.3 & \\
\hline \multirow[t]{2}{*}{ Far vision } & No difficulty & 1077 & 91.6 & 1.0 & 1049 & 88.9 & 1.2 & 0.342 \\
\hline & Some difficulty & 105 & 8.4 & 1.0 & 133 & 11.1 & 1.2 & \\
\hline \multirow[t]{2}{*}{ Near vision } & No difficulty & 1119 & 95.3 & 0.7 & 1098 & 92.7 & 1.0 & 0.076 \\
\hline & Some difficulty & 63 & 4.7 & 0.7 & 86 & 7.3 & 1.0 & \\
\hline \multirow[t]{2}{*}{ Deafness or trouble hearing } & No & 1148 & 97.0 & 0.7 & 1164 & 98.6 & 0.4 & 0.022 \\
\hline & Yes & 39 & 3.0 & 0.7 & 27 & 1.5 & 0.4 & \\
\hline
\end{tabular}


Table 5 Comparison of health care use between 15 to 19 year olds and 20 to 24 year olds in Saudi Arabia, 2013

\begin{tabular}{|c|c|c|c|c|c|c|c|c|}
\hline \multirow[t]{2}{*}{ Health care } & \multirow[t]{2}{*}{ Time range } & \multicolumn{3}{|c|}{$15-19$ years } & \multicolumn{3}{|c|}{ 20-24 years } & \multirow[t]{2}{*}{$P$ value } \\
\hline & & $\mathrm{N}$ & Percent & SE & $\mathrm{N}$ & Percent & SE & \\
\hline \multirow[t]{3}{*}{ Routine checkup } & Within 12 months & 84 & 7.3 & 1.0 & 118 & 10.6 & 1.2 & $<0.001$ \\
\hline & 1 to 5 years & 64 & 5.2 & 0.8 & 108 & 9.4 & 1.1 & \\
\hline & Never or $>5 \mathrm{yr}$ earlier & 993 & 87.5 & 1.3 & 861 & 80.0 & 1.5 & \\
\hline \multirow[t]{3}{*}{ Hospital } & Within 12 months & 481 & 46.7 & 1.9 & 460 & 43.4 & 2.0 & 0.347 \\
\hline & 1 to 5 years & 216 & 17.7 & 1.5 & 224 & 20.5 & 1.6 & \\
\hline & Never or $>5 \mathrm{yr}$ earlier & 427 & 35.6 & 1.8 & 386 & 36.1 & 1.9 & \\
\hline \multirow[t]{3}{*}{ Outpatient clinic } & Within 12 months & 499 & 46.1 & 1.9 & 451 & 39.7 & 2.0 & 0.045 \\
\hline & 1 to 5 years & 195 & 15.8 & 1.4 & 200 & 19.5 & 1.6 & \\
\hline & Never or $>5 \mathrm{yr}$ earlier & 416 & 38.1 & 1.8 & 401 & 40.8 & 2.0 & \\
\hline \multirow[t]{3}{*}{ Physician office visit } & Within 12 months & 483 & 42.8 & 1.9 & 455 & 42.0 & 2.0 & 0.787 \\
\hline & 1 to 5 years & 158 & 12.7 & 1.3 & 143 & 14.0 & 1.5 & \\
\hline & Never or $>5 \mathrm{yr}$ earlier & 449 & 44.5 & 1.9 & 427 & 44.0 & 2.0 & \\
\hline \multirow[t]{2}{*}{ Oral examination } & Within 12 months & 103 & 9.1 & 1.1 & 151 & 13.2 & 1.3 & 0.014 \\
\hline & Never or $>1$ yr earlier & 1112 & 90.9 & 1.1 & 996 & 86.8 & 1.3 & \\
\hline
\end{tabular}

\section{Discussion}

In a national study in KSA, we showed a high prevalence of health risk factors (overweight and obesity, low physical activity, low consumption of fruits and vegetables, high prevalence of high abnormal blood pressure) in Saudi youth. We found that these risk factors are increasing with age and are higher in older youths. Furthermore, we demonstrated that youth are engaging in highly risky behaviors while driving. These findings are of great concern for the KSA health authorities. Our findings call for developing and implementing youthappropriate programs to reduce the burden of disease and to avoid future health challenges.

Although prevalence of overweight and obesity has been previously reported as higher in females compared to males in Saudi adolescents [23] and Saudi adults [17], the prevalence was not considerably different between men and women in our study. This might be due to the decreasing trend of obesity in younger age cohorts of both sexes, which is more prominent in women [17]. Prevalence of obesity was similar to adolescents in the United States (13.7\%), but overweight in our sample (24.1\%) was more common compared to the US adolescent population (16.6\%) [24]. Current smoking among US high school adolescents is higher than in Saudi Arabia (15.7\% versus $8.6 \%$ ); prevalence of current smoking in US men and women is similar $(16.4 \%$ and $15.0 \%$, respectively), while it is very different in KSA (16.1\% in men and $0.8 \%$ in women) [24].

Consumption of fast food and soda or sweetened beverages was high among Saudi youth. Those who never drink soda or pop in KSA were less than US adolescents (10.9 \% vs. $22.3 \%$, respectively) [24]. There was a combination of low physical activity, overweight and obesity, and unhealthy diet in many of the Saudi youths in our study; Washi et al. reported a non-healthy diet with high carbohydrate and fat intake and low calcium, iron, and zinc intake in Saudi adolescents [13]. Pearson and Biddle showed a strong association between sedentary behavior and unhealthy diet [25]. In Saudi Arabia, dietary risk factors, high BMI levels, and high blood sugar levels are amongst the leading causes of disability-adjusted life years [6]. The fact that these risk factors are prevalent at younger ages deserves immediate attention and intervention. Low physical activity was much more prevalent in female youth; public health authorities should push all related sectors to facilitate access for women to health facilities and encourage an active lifestyle for women.

Injuries, especially transport injuries, are among leading causes of mortality and morbidity among youths, both worldwide and in Saudi Arabia [6, 26]. We observed a high prevalence of risky driving and traveling behaviors in Saudi youth. Around three-quarters of young drivers reported that they do not follow speed limits. Moreover, most of the studied Saudi youths reported that they do not use seatbelts as a driver or as a passenger; the percentage of reporting never use of seatbelt as passenger in KSA was $73.5 \%$, compared to $7.6 \%$ in US adolescents [24]. The prevalence is likely to be even higher in reality, as some youth may not report this illegal behavior to interviewers. There is an immediate need for law enforcement by relevant authorities and proper education around the importance of safe driving and traveling behaviors [15].

Hospital/emergency room visits were high among both male and female youths. In fact, they were reported 
more than routine medical checkups and oral health examinations. This practice is not sustainable, even in a wealthy country like KSA. Clearly, many youth are experiencing health problems that they ignore until they need to seek emergency or hospital care. The fact that health care is free in KSA calls for the Ministry of Health to encourage the use of preventive care rather than emergency care. A message to educate and inform youth about the value of preventive care is urgently needed, perhaps through school, as the majority of Saudis attend school [27]. On the other hand, we did not collect further data about the reasons for emergency room or hospital visits; some of these visits might be due to non-urgent problems that can be addressed through outpatient visits.

The unemployment rate among youth in our study was lower than what others have previously reported [5]. However, with KSA's young population, more jobs will be required in the near future. Our study showed that women were less likely to be employed than men. Other studies have explained a gender-based mismatch between education and job opportunities in the Arab world [28]. Future employment plans should take into account the growing population of educated women that will enter the market. Marital status is one of the important demographic indicators that affects social, mental, and physical health. In a country with Islamic rules such as Saudi Arabia, marriage is one of the very few socio-culturally acceptable ways of having a sexual relationship. It potentially affects education, employment, and fertility in the following years.

There is a growing evidence base for action to improve the health of adolescents and young people [29]. The interventions might target diseases, proximal risk factors, or determinants of health. Such interventions will influence incidence and severity of diseases (especially noncommunicable diseases) and injuries at older ages as well as affecting the health status of the current youth population [3, 30]. As part of related interventions, health care providers need to achieve core competencies for appropriate approach to and management of health and development problems of young people; specific attitudes, knowledge, and skills are required for working with youth [31]. The Ministry of Health should ensure that providers are trained in such skills.

This study has some limitations. First, our data are cross-sectional, hence we cannot assess causality. Second, many of our behavioral data, such as smoking, seatbelt use, or physical activity, are self-reported and subject to recall and social desirability biases. Despite these limitations, our study is based on a large sample size and used a standardized methodology for all its measures. We extracted all indices related to adolescence and youth health available through the SHIS data [2], however, there were not enough data on some important aspects of youth health such as sexual behaviors, violence, mental health, and alcohol or drug use.

\section{Conclusion}

The prevalence of health risk factors and risky driving behaviors are very high among Saudi youths. If these current behaviors are not reversed during this crucial age period, the burden of disease will increase in KSA in coming years. Our findings call for immediate interventions to reverse these trends. Youth is an important phase in our lives. It has many challenges and requires more attention and resources for intervention. However, along with the challenges are great opportunities for the future, and changes made in this generation will shape the future health and well-being in the Kingdom. Our findings call for a focused program for youth health in KSA. Prevention should be at the forefront of all activities for better youth health and future health of the Kingdom.

\section{Competing interests}

The authors declare no competing interests. This study was financially supported by a grant from the Ministry of Health of the Kingdom of Saudi Arabia.

\section{Authors' contributions}

AHM conceived and designed the study. MB, ZAM, MAS, and MAA performed the survey. CEB, MT, and FD participated in questionnaire design and interviewers' training. MML, AHM, and CEB analyzed the data. MML, AHM, CEB $M T, F D, M B, Z A M, M A S, M A A$, and AAR drafted or commented on the manuscript. AAR supervised the study. All coauthors are responsible for the content of this article and have read and approved the final manuscript.

\section{Acknowledgement}

We would like to thank Katherine Muller and Amelia Vander Zanden at the Institute for Health Metrics and Evaluation for editing the manuscript

\section{Author details}

${ }^{1}$ Institute for Health Metrics and Evaluation, University of Washington, 2301 Fifth Ave, Suite 600, Seattle, WA 98121, USA. ${ }^{2}$ Ministry of Health of the Kingdom of Saudi Arabia, Assadah, Al Murabba Riyadh 12613, Saudi Arabia.

Received: 29 July 2015 Accepted: 29 February 2016

Published online: 05 March 2016

\section{References}

1. Definition of youth [http://www.un.org/esa/socdev/documents/youth/factsheets/youth-definition.pdf].

2. Patton GC, Coffey C, Cappa C, Currie D, Riley L, Gore F, et al. Health of the world's adolescents: A synthesis of internationally comparable data. Lancet. 2012;379:1665-75

3. Catalano RF, Fagan AA, Gavin LE, Greenberg MT, Irwin CE, Ross DA, et al. Worldwide application of prevention science in adolescent health. Lancet. 2012;379:1653-64.

4. Nutbeam D. Indicators of adolescent health: expanding the framework for assessing health status among young people. Promot Educ. 1997:4:10-4.

5. Murphy C. Saudi Arabia's Youth and the Kingdom's Future. 2011.

6. Memish ZA, Jaber S, Mokdad AH, AlMazroa MA, Murray CJL, Al Rabeeah AA, et al. Burden of disease, injuries, and risk factors in the Kingdom of Saudi Arabia, 1990-2010. Prev Chronic Dis. 2014;11:E169.

7. Abalkhail B. Overweight and obesity among Saudi Arabian children and adolescents between 1994 and 2000. East Mediterr Health J Rev Santé Méditerranée Orient Al-Majallah Al-Sihhīyah Li-Sharq Al-Mutawassit. 2002:8:470-9.

8. Al-Daghri N, Alokail M, Al-Attas O, Sabico S, Kumar S. Establishing abdomina height cut-offs and their association with conventional indices of obesity among Arab children and adolescents. Ann Saudi Med. 2010;30:209-14. 
9. El Mouzan MI, Foster PJ, Al Herbish AS, Al Salloum AA, Al Omer AA, Qurachi MM, et al. Prevalence of overweight and obesity in Saudi children and adolescents. Ann Saudi Med. 2010;30:203-8.

10. Abahussain NA, Musaiger AO, Nicholls PJ, Stevens R. Nutritional status of adolescent girls in the eastern province of Saudi Arabia. Nutr Health. 1999;13:171-7.

11. Farahat FM, Joshi KP, Al-Mazrou FF. Assessment of nutritional status and lifestyle pattern among Saudi Arabian school children. Saudi Med J. 2007;28:1298-300.

12. Madani KA, Al-Amoudi NS, Kumosani TA. The state of nutrition in Saudi Arabia. Nutr Health. 2000;14:17-31.

13. Washi SA, Ageib MB. Poor diet quality and food habits are related to impaired nutritional status in 13- to 18-year-old adolescents in Jeddah. Nutr Res N Y N. 2010;30:527-34.

14. El Bcheraoui C, Basulaiman M, Tuffaha M, Daoud F, Robinson M, Jaber S, et al. Status of the diabetes epidemic in the Kingdom of Saudi Arabia, 2013. Int J Public Health. 2014;59:1011-21.

15. El Bcheraoui C, Basulaiman M, Tuffaha M, Daoud F, Robinson M, Jaber S, et al. Get a license, buckle up, and slow down: risky driving patterns among Saudis. Traffic Inj Prev. 2014.

16. El Bcheraoui C, Memish ZA, Tuffaha M, Daoud F, Robinson M, Jaber S, et al. Hypertension and its associated risk factors in the kingdom of saudi arabia, 2013: a national survey. Int J Hypertens. 2014;2014:564679.

17. Memish ZA, El Bcheraoui C, Tuffaha M, Robinson M, Daoud F, Jaber S, et al. Obesity and associated factors-Kingdom of Saudi Arabia, 2013. Prev Chronic Dis. 2014;11, E174.

18. Basulaiman M, El Bcheraoui C, Tuffaha M, Robinson M, Daoud F, Jaber S, et al. Hypercholesterolemia and its associated risk factors-Kingdom of Saudi Arabia, 2013. Ann Epidemiol. 2014;24:801-8.

19. Moradi-Lakeh M, El Bcheraoui C, Tuffaha M, Daoud F, Al Saeedi M, Basulaiman M, et al. Tobacco consumption in the Kingdom of Saudi Arabia, 2013: findings from a national survey. BMC Public Health. 2015;15:611.

20. Moradi-Lakeh M, El Bcheraoui C, Tuffaha M, Daoud F, Al Saeedi M, Basulaiman $M$, et al. Self-Rated Health Among Saudi Adults: Findings from a National Survey, 2013. J Community Health. 2015:40(5):920-6.

21. Centre for disease control and prevention. National Health and Nutrition Examination Survey (NHANE). Health Tech/Blood Pressure Procedures Manual. 2009.

22. Booth ML, Ainsworth BE, Pratt M, Ekelund U, Yngve A, Sallis JF, et al. International physical activity questionnaire: 12-country reliability and validity. Med Sci Sports Exerc. 2003;195:3508-1381.

23. Mahfouz AA, Shatoor AS, Khan MY, Daffalla AA, Mostafa OA, Hassanein MA. Nutrition, physical activity, and gender risks for adolescent obesity in Southwestern Saudi Arabia. Saudi J Gastroenterol Off J Saudi Gastroenterol Assoc. 2011;17:318-22.

24. Kann L, Kinchen S, Shanklin SL, Flint KH, Kawkins J, Harris WA, et al. Youth risk behavior surveillance-United States, 2013. MMWR Surveill Summ. 2014:63(4):1-168.

25. Pearson N, Biddle SJH. Sedentary behavior and dietary intake in children, adolescents, and adults. A systematic review. Am J Prev Med. 2011:41:178-88,

26. GBD 2013 Mortality and Causes of Death Collaborators. Global, regional, and national age-sex specific all-cause and cause-specific mortality for 240 causes of death, 1990-2013: a systematic analysis for the Global Burden of Disease Study 2013. Lancet. 2014;385(9963):117-71.

27. El Bcheraoui C, Tuffaha M, Daoud F, AlMazroa MA, Al Saeedi M, Memish ZA et al. Low uptake of periodic health examinations in the Kingdom of Saudi Arabia, 2013. J Fam Med Prim Care. 2015:4:342-6.

28. Obermeyer CM, Bott S, Sassine AJ. Arab Adolescents: Health, Gender, and Social Context. J Adolesc Health Off Publ Soc Adolesc Med. 2015:57:252-62.

29. Bustreo F, Chestnov O. Emerging Issues in Adolescent Health and the Positions and Priorities of the World Health Organization. J Adolesc Health. 2013;52:S4.

30. Dick B, Ferguson BJ. Health for the World's Adolescents: A Second Chance in the Second Decade. J Adolesc Health. 2015;56:3-6.

31. World Health Organization. Core Competencies in Adolescent Health and Development for Primary Care Providers. Geneva, Switzerland: WHO Press; 2015.

\section{Submit your next manuscript to BioMed Central and we will help you at every step:}

- We accept pre-submission inquiries

- Our selector tool helps you to find the most relevant journal

- We provide round the clock customer support

- Convenient online submission

- Thorough peer review

- Inclusion in PubMed and all major indexing services

- Maximum visibility for your research

Submit your manuscript at www.biomedcentral.com/submit 